Published in final edited form as:

Adv Drug Deliv Rev. 2015 April ; 84: 198-207. doi:10.1016/j.addr.2014.07.007.

\section{Coaxing stem cells for skeletal muscle repair}

\author{
Karl J.A. McCullagh ${ }^{1}$ and Rita C. R. Perlingeiro ${ }^{2}$
}

${ }^{1}$ Department of Physiology, School of Medicine and Regenerative Medicine Institute, National University of Ireland Galway, Ireland '2Lillehei Heart Institute, Department of Medicine, University of Minnesota, Minneapolis, MN, USA

\section{Abstract}

Skeletal muscle has a tremendous ability to regenerate, attributed to a well-defined population of muscle stem cells called satellite cells. However, this ability to regenerate diminishes with age and can also be dramatically affected by multiple types of muscle diseases, or injury. Extrinsic and/or intrinsic defects in the regulation of satellite cells are considered to be major determinants for the diminished regenerative capacity. Maintenance and replenishment of the satellite cell pool is one focus for muscle regenerative medicine, which will be discussed. There are other sources of progenitor cells with myogenic capacity, which may also support skeletal muscle repair. However, all of these myogenic cell populations have inherent difficulties and challenges in maintaining or coaxing their derivation for therapeutic purpose. This review will highlight recent reported attributes of these cells and new bioengineering approaches to creating a supply of myogenic stem cells or implants applicable for acute and/or chronic muscle disorders.
\end{abstract}

\title{
Keywords
}

Satellite cells; mesenchymal stem cells; pluripotent stem cells; muscular dystrophy; muscle regeneration; niche; bioengineering

\section{Introduction}

Skeletal muscle is a vitally important tissue to normal whole body function and homeostasis. This mass of fibrous tissue makes up nearly half a person's body weight. The role of skeletal muscle in the body is beyond its critical involvement in movement, breathing, and posture. For instance, skeletal muscle is a major regulator of blood glucose levels, and consequently, a defect in the mechanism of muscle insulin cell signalling is the main contributor to type II diabetes [1-7]. There are other examples of metabolic diseases linked to defects in skeletal muscle including the McArdle syndrome. McArdle syndrome is caused by a mutation in the

(C) 2014 Elsevier B.V. All rights reserved.

Corresponding Author: Rita C.R. Perlingeiro PhD, Lillehei Heart Institute, University of Minnesota, 4-128 CCRB, 2231 6th St. SE, Minneapolis, MN 55455, USA, perli032@umn.edu, Phone: 612625 4984, Fax: 6123018298.

Publisher's Disclaimer: This is a PDF file of an unedited manuscript that has been accepted for publication. As a service to our customers we are providing this early version of the manuscript. The manuscript will undergo copyediting, typesetting, and review of the resulting proof before it is published in its final citable form. Please note that during the production process errors may be discovered which could affect the content, and all legal disclaimers that apply to the journal pertain. 
glycogen phosphorylase gene resulting in an inability to breakdown muscle glycogen which ultimately leads to rhabdomyolysis $[1,2,8-12]$. Therefore, skeletal muscle is a key target for therapy in metabolic diseases.

Maintenance of healthy muscle is essential for everyday organ activities, the ocular muscles that surround the eyeball, sphincter muscles for excretion of waste, and the diaphragm muscles essential for respiration. Skeletal muscle is susceptible to numerous dysfunctions that contribute to disease or pathological states including, muscular dystrophies (primary defect is in muscle), neuromuscular disorders (defect is in neural control of muscle), sarcopenia (ageing associated decrements in muscle), cachexia (cancer induced muscle loss), and metabolic disorders. There are over 100 muscle diseases identified in humans (see http://www.musclegenetable.fr/ for an updated list). Skeletal muscle can also be subject to injury from mild lacerations to more severe volumetric muscle loss. Therefore, understanding the mechanisms of skeletal muscle repair is essential for development of therapies for muscle disease, injury and ageing associated defects that can accelerate morbidity and mortality. In this review we will refer mostly to muscular dystrophies and ageing, but mechanisms and therapeutic strategies discussed may apply to many muscle deficiencies associated with diseases, pathologies and injury.

\section{Muscular dystrophy and Ageing}

Muscular dystrophy (MD) refers to a group of genetic muscle diseases caused by inherited mutations in muscle proteins that result in progressive muscle weakness, degeneration and muscle cell death [10,13-16]. The most prevalent form is Duchenne Muscular Dystrophy (DMD), an X-linked lethal disorder that affects 1 in 5000 male live births [1,13,16-21]. DMD is caused by mutations in dystrophin, the largest gene in the human genome $[18,22,23]$. The absence of dystrophin protein causes the loss of cell membrane integrity, activating a cascade of cellular events that leads to degeneration of the muscle cell. Degeneration is accompanied by successive cycles of regeneration by the muscle stem cell pool, called satellite cells (SC), which eventually becomes depleted. Over time, muscle tissue is substituted with fat and connective tissue [2,6,7], muscle becomes atrophic and consequently, the capacity to restore skeletal muscle function is lost $[2,11]$. Clinically, DMD patients are confined to a wheelchair, and their life span is shortened due to cardiorespiratory problems. A milder dystrophic disease is Becker's Muscular Dystrophy due to mutations resulting in partial dystrophin deficiency. Dystrophin is associated with a complex of proteins, which includes three subcomplexes: the dystroglycan complex, the sarcoglycan complex and the cytoplasmic complex consisting of syntrophins and a-dystrobrevin. The dystrophin protein complex (DPC) functions by providing mechanical support to the muscle cell. The structural role of the DPC is evident from gene deletion studies on members of the DPC, many of which result in muscle degeneration, including sarcoglycan mutations causing Limb-Girdle muscular dystrophy.

A number of different strategies are being attempted to combat skeletal muscle disorders, which include drug, gene and cell therapy or a combination of these. Pharmacological targets include nitric oxide production, which is reduced in several muscular dystrophies $[10,14]$. The production of nitric oxide has been stimulated by nitric oxide donors or 
phosphodiesterase inhibitors which have had efficacy in animal studies and now in clinical trials $[13,16,17]$. Drug screens to identify ways to up-regulate the dystrophin homologue utrophin have also been of major focus in academic and commercial ventures [1,24]. Gene therapy has been heavily focused on delivering micro-dystrophin genes (due to gene packaging size limitations of appropriate vectors) into muscle using adeno-associated viruses (AAV) [1,4]. More recently, the size limitation issue of AAV has been overcome by implementing a triple-AAV vector system to successfully express full-length dystrophin in mice $[25,26]$. However, unexpected immune responses to dystrophin delivery observed during clinical trials is an added challenge that is under address now [1,9]. Partially recovering dystrophin by exon skipping appears to be an alternative approach that is generating optimistic results in the clinic [8,27].

Skeletal muscle has a remarkable ability to regenerate. However, skeletal muscle is susceptible to a drastic decline in regenerative capacity with advanced age, a phenomenon known as sarcopenia. Sarcopenia is linked to loss of muscle mass and function, and has a severely debilitating impact on quality of life in aged people. Some symptoms are shared with muscular dystrophy including a limited capacity to regenerate new muscle fibres, and the presence of inflammation. The limited capacity to regenerate is determined by cellintrinsic and/or environment influences on the stem cells within muscle, which we will refer to in this review.

\section{Stem Cells and Regeneration}

The body's tissues show varied capacities to regenerate from nil to extensive, determined by the absence or presence of a tissue specific stem cell pool. A stem cell is defined as a cell that persists for the lifetime of the organism and continues both to reproduce itself (selfrenew) and generate differentiated progeny $[2,6,7,18,23]$. Stem cells have been categorized in terms of their behaviour and potency to differentiate into certain cell types. Most stem cells we are interested in from a therapy stance are either pluripotent, multipotent or unipotent. Skeletal muscle has a tremendous ability to regenerate due to the mobilization of its own well defined tissue-specific muscle stem cells, known as satellite cells (SC) $[2,6,7,11]$, which are a potential target for therapeutic application in many muscle diseases, in particular muscular dystrophies $[2,10,11,14]$. Other stem cell populations with muscle regenerative potential have also been investigated, some of which will be discussed below. Recent new developments in muscle stem cell research may circumvent some of the therapeutic challenges confronting researchers in curing DMD and other aforementioned muscle disorders. This review focuses on some of those new developments in our understanding of the regulation and derivation of muscle stem/progenitor cells with relevance to the engineering of skeletal muscle for repair

\subsection{Satellite Cells}

The satellite cell (SC) population is the main cell source for muscle regeneration (see Fig.1) and growth (fusion of newly induced muscle cells) of skeletal muscle. To replenish or substitute this finite pool of SCs with normal or gene corrected stem cells is a major focus of some DMD research (see Fig.2). Satellite cells are located between the basal lamina and the sarcolemma of the muscle fibre. Satellite cells make up $2-7 \%$ of the nuclei in adult murine 
muscle, are higher in oxidative muscles and notably, reside in close proximity to blood capillaries $[1,4,24]$. They display several cell surface and nuclear biomarkers foremost being the expression of the paired box transcription factors Pax 7 and/or Pax $3[1,4,9]$. Pax 7 is the canonical SC biomarker expressed across several species in both quiescent and proliferating SCs (Fig. 1). Pax3 is a paralog of Pax7 but is associated with certain anatomical located muscles including the diaphragm and trunk muscles of the body $[1,8,9,27]$. In fact, SCs appear to exist as heterogeneous populations isolated with different cell surface biomarkers and showing variation in their efficiency to regenerate muscles in vivo. Proof of the concept of muscle stem cell came from single myofibre transplantation studies. In one seminal study, muscle fibers with SCs were isolated and transplanted into radiation-ablated muscles of mdx/nude (immunodeficient) mice [8,27]. A single myofibre with as few as seven SCs gave rise to over a hundred new muscle fibres. Moreover, the SCs were seen to self-renew and strongly expanded themselves. A later study isolated single SCs by flow cytometry and transplanted into irradiated muscles [28]. Remarkably, a single SC was able to proliferate, differentiate and self-derive Pax-7+ SCs after engraftment. Many studies have now entailed isolating putative satellite cell populations and shown a wide variation in the extent of engraftment upon transplantation into animal models [1]. The wide variation in efficacy may in part be due to the variation in purification strategies used [29] [30]. The majority of purification studies make use of fluorescence activated cell sorting (FACs). This entails digestion of the muscle tissue into single cells followed by labeling of cells with fluorescent conjugated antibodies against specific SC surface markers and non-SC markers. Most laboratories use the same negative markers to isolate SCs (CD31, CD45, Sca-1 and Mac-1), but differ somewhat in the panel of positive markers (SM/C-2.6 or Integrin or CXCR4 or CD34) [29]. Heterogeneity of progenitor populations purified from skeletal muscle by surface markers has made it difficult to quantify the functional regenerative potential of primary satellite cells. However studies with cells purified on the basis of Pax7 expression [31] have shown that as few as 900 cells can generate new muscle with measurable force generation capability [32]. Another clearly important determinant of SC function that can be exploited for the bioengineering of muscle is the niche microenvironment that the $\mathrm{SC}$ resides in, aspects of which we will discuss below.

3.1.1 Satellite Cell Niche-Like other adult stem cells, SCs have a unique niche environment, which includes an extracellular matrix (ECM), vascular and neural networks, an array of distinct cells and diffusible molecules. The SC niche appears to be crucial for maintaining their stem cell properties i.e. quiescence, self-renewal, proliferation, and myogenic differentiation. This is evident as when SCs are isolated and grown in culture, they begin to lose their stem cell properties, and as a result lose their capacity to regenerate muscle in vivo [28,33]. The use of biomaterials in designing three-dimensional scaffolds for seeding therapeutic cells for transplantation into the patient is a topical area of tissue engineering. The goal of the tissue engineer is to design a scaffold that mimics the environmental niche of the stem cell and thereby help retain the stem cell's innate characteristics.

3.1.2 Extrinsic Biophysical Cues-Amongst the niche components those that alter the stiffness of the substrata that cells are adhered to in vivo or in vitro can highly influence stem 
cell activity. Notably, it has been documented that mesenchymal stem cells (discussed below) grown on different tensile strength matrices can surprisingly affect lineage specification to nerve, muscle or bone in identical media conditions [34]. In a similar context for muscle, it is apparent that the stiffness of the substrata that the SCs are exposed to, which is reflective of the extracellular matrix (ECM) make-up and surrounding cells, is highly influential on their proliferation, differentiation and self-renewal capacity [35,36]. The ECM consists of collagen, laminin, fibronectin, entactin, and other proteoglycans and glycoproteins. Muscular dystrophies and aging are both associated with large amounts of fibrosis caused by an accumulation of ECM components particularly collagen [37,38]. The importance of the SC niche rigidness has been highlighted by recent work from the Blau laboratory [35]. They have introduced the use of a hydrogel for growing isolated SCs on. The hydrogel was made from commonly used laboratory polyacrylamide in which the concentration of bis-acrylamide crosslinking sets the elasticity [39]. Gels were coated with collagen I to promote both cell adhesion and myogenic differentiation [40] The hydrogel was able to mimic the stiffness and physical forces that the SCs are normally exposed to in its microenvironment niche in vivo. It was reported that SCs cultured on a gel matrix with an elastic stiffness (Young's modulus) of $\sim 12 \mathrm{kPa}$ was optimal for maintaining cells in an undifferentiated state in vitro, and their regenerative capacity when subsequently injected into radiation-ablated mice [35]. It was also observed that cells cultured on gels with lower $(2 \mathrm{kPa})$ or higher $(42 \mathrm{kPa})$ rigidity had a compromised ability to proliferate and differentiate into muscle [35]. Interestingly, healthy muscle has a stiffness of $12 \mathrm{kPa}$ and dystrophindeficient or aged muscles exemplify a more rigid state of $\sim 18 \mathrm{kPa}[40,41]$. The biophysical properties of these muscles is likely determined by the increased ECM deposition (principally collagen production) due to infiltrating fibroblasts resulting from the fibrosis associated with both muscular dystrophies and ageing [42]. Standard cell culture plastics normally used to grow tissue stem cells are 100,000 fold more rigid than any soft tissue [43]. Thus the expansion of isolated SCs for cell therapy would benefit from improvements in the elasticity of the surface used to grow them. In addition, myopathic disease states may benefit from the engraftment of stem cells on a patch or scaffold that would mimic these optimal biophysical forces. Noteworthy, is that muscle cell patches have been transplanted into $m d x$ mice and were seen to contribute to enhancing dystrophin positive muscle fibres [44].

The influence of ECM elasticity on SC activity has been further highlighted by recent findings in collagen VI $\left(\mathrm{Col}^{-/-}\right)$deficient mice [36]. $\mathrm{Col}^{-/-}$mice display a muscle wasting phenotype resembling human conditions associated with COL6 gene mutations, as observed in Bethlem myopathy and Ullrich congenital muscular dystrophy [45]. Col6 ${ }^{-1-}$ mice were observed to have a reduced ECM stiffness of $\sim 7 \mathrm{kPa}$ versus a normal elasticity of $\sim 12 \mathrm{kPa}$, and that collagen VI deficiency could be rescued by the engraftment of wild-type muscle fibroblasts that are known to secrete collagen VI. The secretion of collagen VI re-established the normal plasticity of the ECM, which rectified the self-renewal and proliferative capacity of the Col6 null SCs. This study indicates that the ECM protein collagen VI plays a key role in maintaining normal elasticity of skeletal muscle, which is crucial for normal SC activity. Therefore, from the above aforementioned studies, it appears that there is a bell- shaped curve relationship between muscle extracellular stiffness (mechanical compliance of matrix and adjacent cells) and stem cell activity (self-renewal capacity). Muscle elasticity below 
( $\sim 7 \mathrm{kPa}$ in collagen IV knock-out mice) or above the elastic modulus of $12 \mathrm{kPa}(>18 \mathrm{KPa}$ in aged or dystrophin deficient dystrophic mice) diminishes SC activity. The relationship between elasticity and muscle cell function has been examined in $\mathrm{C} 2 \mathrm{C} 12$ cells. $\mathrm{C} 2 \mathrm{C} 12$ cells were shown to have greatly reduced differentiation on softer $(<5 \mathrm{kPa})$ and stiffer $(>20 \mathrm{KPa})$ substrate surfaces that the cells were grown on [40]. Thus, the elasticity of diseased muscle may explain the poor effect of gene and cell therapies in alleviating fibrotic muscle diseases like muscular dystrophy [46]. The combination of reducing fibrosis via genetic and/or pharmacological inhibition prior to stem cell delivery maybe essential to maximize efficacy of all stem cell-based muscle therapies. There may also be an opportunity for a biomaterial intervention with the goal of mimicking the optimal elasticity for stem cell function within the fibrotic muscle tissue.

3.1.3. Intrinsic Biochemical Cues-Previous reports suggest that the diminished ability of SCs to self-renew as we age are mainly due to alterations in the microenvironment cues (see 3.1.2. and 3.1.4.) and not due to the intrinsic nature of the SCs per se $[47,48]$. However, several studies have readdressed this question with some enlightening findings (see Table 1.). Recently, the Blau laboratory examined this by isolating SCs from young and old mice and explanting them back into young mice respectively [49]. They established that there are clear-cut intrinsic defects in the aged SCs and that a young microenvironment cannot rescue this. This was only apparent when low numbers of SCs were explanted into young mice as when large numbers were used it masked detection of the functional defect. These investigators identified that elevations in $\mathrm{p} 38$ contributed to the defect in SCs from aged mice, and that transient inhibition of p38 enhanced SC activity and muscle regeneration in these mice. Furthermore, genetic suppression of p38 coupled with growing the aged SCs on hydrogels with an elasticity of $12 \mathrm{kPa}$ had a synergistic effect in stimulating SC activity, muscle regeneration and improved in situ measured contractile parameters [49]. Therefore, these studies indicate that SCs from aged animals have intrinsic defects that are not corrected by exposure to a young environment. Furthermore, both biochemical and biophysical cues can rejuvenate these cells. In parallel, a second recent study examined p38 mitogen-activated protein kinase signaling in SCs from aged mice [50]. They demonstrated that pharmacological partial inhibition of p38 re-awakened the SCs from aged mice, restoring several defects including: generation of Pax7+ cells, increased asymmetric division and self-renewal, and rescued engraftment and maintenance of these cells in regenerating muscles [50]. Noteworthy, complete inhibition of p38 blocked self-renewal, indicating that p38 is required for SC self-renewal. Concurrently, another study has also definitively identified that SCs from ageing mice have intrinsic defects that contribute to the reduction in regenerative capacity over and above any influence of the environment [51]. The authors using a micro-array analysis of isolated SCs from different aged sarcopenic and nonsarcopenic mice identified p16 ${ }^{\mathrm{INK} 4 \mathrm{a}}(\mathrm{Cdkn} 2 \mathrm{a})$ as a candidate gene that might contribute to these intrinsic defects. By genetically altering $\mathrm{p} 16^{\mathrm{INK} 4 \mathrm{a}}$ in SCs they established that derepression of $\mathrm{p} 16^{\mathrm{INK} 4 \mathrm{a}}$ causes aged SCs to switch from a quiescent to a pre-senescent state. $\mathrm{p} 16^{\mathrm{INK} 4 \mathrm{a}}$ is a tumor suppressor gene and the master regulator of cellular senescence. Therefore, the inhibition of $\mathrm{p} 16^{\mathrm{INK} 4 \mathrm{a}}$ becomes another therapeutic strategy to prevent the regenerative capacity decline associated with sarcopenia. 
3.1.4. Extrinsic Biochemical Cues-There are multiple intrinsic/extrinsic biochemical factors that regulate $\mathrm{SC}$ function and are derived from the circulation, the satellite cell itself or the adult muscle fiber. Some of these identified factors are highlighted in table 1.

Notably, Notch signaling appears prevalently involved in many of the actions of these biochemical cues on SCs [52]. Notch principally affects SCs by maintaining them in an undifferentiated quiescent state [53] [54]. In healthy skeletal muscle the majority of SCs reside in a quiescent state. Upon injury or disease the SCs become activated and undergo asymmetric and/or symmetric divisions. Asymmetric division leads to both a population of muscle committed cells and self-renewing stem cells. Symmetric division generates two identical populations of self-renewing stem cells. Notch signaling cascade is mediated by the transmembrane Notch ligand Delta binding to one of a family of Notch receptors. During ageing Delta ligand expression is diminished in myofibers and SCs, resulting in decreased Notch signaling in SCs $[47,55]$. Consequently, there is an increased propensity for SCs to differentiate leading to a reduced ability to maintain SC number [47,55]. However, the full actions of Notch appear to be cell context dependent and complicated by the unresolved function of multiple ligands and receptors [52].

Several growth factors have been demonstrated to regulate muscle regeneration by directly affecting SC function, including, Wnts, TGF- $\beta$, FGF and IGF-1. These factors are able to mediate their effects via the systemic circulation or secretion from the myofiber or neighboring cells [56]. Specifically, Wnt3a has been reported to increase in aged muscle, reducing muscle regeneration by blunting Notch signaling and increasing fibrosis by defective SC function [57,58]. In contrast, Wnt7a promotes symmetric SC division and helps maintain self-renewal of the SC pool [19]. Exogenous delivered Wnt7a has also been shown to ameliorate DMD in mice and improve muscle contractile function [59]. Most recently, decrements in circulating TGF- $\beta$ family member, GDF- 11 has been implicated in causing increases in DNA damage in SCs contributing to their dysfunction in ageing mice [22]. Moreover, delivery of recombinant GDF-11 protein into aged mice rejuvenated skeletal muscle regeneration capacity while reducing DNA damage in aged SCs to levels observed in SCs from young mice [22].

3.1.5 Bioengineering of muscle: mimicking the niche-Several studies have documented the development of biomimic materials in aid of muscle repair (see reviews $[60,61])$. A recent report has described significant functional efficacy when they explanted a photopolymerizable hydrogel complex embedded with SCs into surgically partially ablated mouse hindlimb muscles [62]. Notably, there was functional muscle recovery as determined from the in vivo measured isometric force output. The exogenous SCs engrafted into the host's niche, which is essential to support subsequent rounds of regeneration. In addition, the hydrogel-SC complex integrated the formation of neural and vascular networks. This combination of effects in repairing the muscle niche is thought to have been essential for muscle functional recovery and is a nice example of biomaterial based muscle engineering. Similarly, in another study the vessel-associated mesoangioblasts (see 3.2. for description) were embedded in a hydrogel cell carrier made of polyethylene glycol-fibrinogen. The hydrogel encapsulated cells formed a resorbable cellularized implant which improved mesoangioblast engraftment in both acutely injured muscles and late stage dystrophic 
muscles of mice respectively [63]. Continued new developments in making more and more sophisticated hydrogels that mimic the stem cell niche will likely have a continued impact on novel strategies for regenerative medicine [64] [65].

Others have engineered whole muscles in vitro such that they retain their SCs and regenerative capacity similar to native muscle, and then showed successful implantation of these biomimetic muscles into immune deficient mice [66]. The engineered muscles were created by culturing and differentiating neonatal rat muscle cells. Muscle cells were further engineered by anchoring the fibres end to end with tendon-mimetic Velcro tabs pinned inside a polydimethylsiloxane well. An exhaustive number of experiments were undertaken to show that biomimetic muscles could generate contractile force, had a native-like niche with quiescent SCs and had the capacity to regenerate after toxin-induced in vitro injury. The in vivo ability of the engineered muscles was further examined using a mouse dorsal window implantation model. Muscle bundles were implanted into a skinfold window chamber on the back of nude mice. The skinfold contains a dermal muscle layer, which the muscle bundles were seen to thrive on, over a two week period. Dramatically, the engineered muscles became increasingly vascularized and integrated with the host muscle. Muscle fibres hypertrophied and also responded to a toxin induced injury challenge at the expense of a reduction in the muscles SC pool. Increases in detected calcium spikes paralleled a progressive increase in maximal contractile force output such that muscles could contract as strongly as native neonatal skeletal muscle by two weeks post-implantation [66]. This is the first demonstration of a bioengineered muscle that is able to regenerate in both in vitro and in vivo models of muscle injury. Furthermore, the biomimetic muscles produced 10-100 fold higher contractile-force amplitudes compared to other previously in vitro engineered muscles [67] [68] [69] [70] [71]. Others have shown that engineered muscles transplanted into mice can partially fulfill the functional properties of an excised muscle [71].

The development of engineering skeletal muscle that mimics the complexity of native muscle will have implications in regenerative medicine including repair strategies for injuries or trauma associated with muscle damage or loss, and diseases where a limited number of muscles are affected, such as in oculopharyngeal muscular dystrophy and facioscapulohumeral dystrophy. In addition, biomimetic muscles may also provide an alternative model to study the pathophysiology of muscle in vitro [71].

\subsection{Other resident skeletal muscle stem cells}

Apart from SCs, several other resident skeletal muscle stem cells have been reported to possess regenerative potential [72][73]. We will describe some of these stem cell preparations that have shown significant functional and/or morphological benefits to disease states such as muscular dystrophy. One of these refer to a population of myogenic cells isolated based on their adherence to collagen-coated plates and called muscle derived stem cells (MDSCs) [74]. MDSCs have the capacity to self-renew and differentiate into mesodermal lineages. Recently, a form of MDSCs, called MuStem cells, were derived from dogs and transplanted into the canine DMD model [75]. Intra-arterially injected MDSCs had some therapeutic benefits, including muscle fiber regeneration with re-expression of 
dystrophin, replenishment of the SC pool, and increased physical mobility compared to mock treated dogs [75]. Besides the muscle differentiation capacity of MDSCs, they also appear to have a potent paracrine action which may significantly contribute to observed benefits in muscle and ageing disorders [76] [77].

Another population of muscle stem cells, isolated based on the expression of the cell surface glycoprotein CD133 using flow cytometry, has been reported by Torrente and colleagues [78]. These authors have isolated muscle-derived CD133+ stem cells from DMD patients and genetically corrected these to express a functional form of dystrophin. The genetically corrected human CD133+ cells were transplanted into immunodeficient dystrophic mice and showed recovery of dystrophin expression, regeneration of muscle fibers and notably, greater in vitro and in vivo measured muscular force output [78-80].

A distinct class of mesenchymal-like stem cells associated with the vasculature, known as mesoangioblasts, have shown promising therapeutic benefits in dystrophic muscles of several species $[10,81]$. The marker signature of mesoangioblasts indicates that they are distinct from SCs and are in fact a subgroup of pericytes which can be found in the muscle microvasculature [82]. Mesoangioblasts have been successfully used for ex-vivo gene correction studies in both $m d x$ mice [16] and the golden retriever muscular dystrophy dog model [10]. Notably, in the former study gene correction entailed episomal delivery of the entire human dystrophin genetic locus into autologous derived mesoangioblasts, followed by cell engraftment into the $m d x$ mouse [16]. Based on these studies a human clinical trial began and is near completion (EudraCT no. 2011-000176-33). However, there are already some recognized limitations in this first attempt at stem cell delivery into DMD patients [83]. Nevertheless, the trial will provide valuable safety information on stem cell delivery to DMD patients [83].

\subsection{Mesenchymal stem cells}

Mesenchymal stem cells (MSCs) or stromal cells are already in clinical trial usage for several pathologies and diseases, such as congestive heart failure, graft-versus-host disease, chronic obstructive pulmonary disease, type 1 diabetes (see review [84]). MSCs have many advantages over other stem cell preparations; in particular their reasonably easy isolation from bone marrow (BM) or adipose tissue, among others. The cells are multipotent as they can differentiate into some mesodermal lineages including bone, cartilage, and fat. In addition, MSCs have a unique ability to suppress immuno-inflammatory responses (review $[85,86])$. Therefore transplantation of MSCs could be better tolerated when compared to other stem cell preparations. It has been proposed that these cells could be useful for gene defected diseases such as DMD where allogeneic cell engraftment could aid delivering the dystrophin gene without genetic intervention [87]. MSCs isolated from BM and adipose tissues have been shown to assume a skeletal myogenic fate (Review [88]), although the latter source is claimed to have a greater propensity for muscle differentiation [89]. Nevertheless, to date there has been no high-yield cell engraftment of MSCs into animal skeletal muscle and in contrast to their tri-lineage differentiation capacity, MSCs do not easily differentiate into myogenic cells. This is supported by MSC transplantation studies in 
dystrophic mice reporting that MSC engraftment does not result in functional benefit [90], which may also be due to lack of or limited MSC differentiation into skeletal muscle.

3.3.1. Coaxing MSCs to skeletal muscle?-Recent studies have revealed the unexpected plasticity of somatic cells to be reprogrammed to an embryonic-like stem cell by transient expression of four early developmental transcription factors [91]. On similar rationale, others have demonstrated transdifferentiation of somatic cells by overexpression of "master regulatory" transcription factors e.g. cardiac fibroblasts converted to beating cardiac myocytes [92]. MSCs have been treated to express master regulatory factors MyoD or Pax3. MyoD- and Pax3-MSCs engraft into skeletal muscle respectively and differentiate towards the host lineage $[90,93,94]$. However the differentiation of MSCs is incomplete as they continue to express MSC genes along with skeletal muscle genes. This incomplete transformation to the skeletal muscle lineage is suggested to be the reason for the poor efficacy of MSCs in skeletal muscle repair. In conclusion, with current methods, MSCs do not readily support skeletal muscle repair, but their anti-inflammatory [85] and paracrine [95] characteristics may be an alternative benefit for treating muscle disease.

3.3.2. Biomaterial and MSC muscle differentiation-Some investigators have exploited whether MSC derived myogenic cell differentiation could be improved through the use of biomaterials. The Engler laboratory have examined the influence biophysical forces have on bone- (BMSCs) and adipose- (ASCs) derived MSCs in promoting muscle lineage differentiation [89]. It was observed that plating the MSCs on a matrix of fibronectin covered acrylamide, mimicking the muscle ECM elasticity, enhanced myogenic conversion for MSCs from both origins. They further identified that ASCs not only had a greater propensity to form fused myotubes but that these multinucleated myotubes were maintained on a stiff matrix resembling the more rigid substrata found in fibrotic tissue (as discussed in 4.1.2). In contrast, BMSCs lost their myogenic capacity on the more stiffened matrix. As previously mentioned, the more stiffened matrix in aged or myopathic muscle is thought to reduce the therapeutic capacity of stem cells. It will be interesting to examine if the enhanced myogenic capacity of these ASCs will elicit functional contractile benefits in myopathic muscle, given the lack of reported muscle functional efficacy for MSC delivery into models of muscle disorders to date [90].

3.3.3 Non-myogenic Mesenchymal progenitors-Separate from the bone- and adipose-derived MSCs, a pool of MSCs within skeletal muscle has been identified termed Fibro/Adipogenic Progenitors (FAPs) distinct from SCs and not to be confused with fibroblast activation protein-a $\left(\mathrm{FAP}^{+}\right)$-expressing stromal cells [96]. FAPs were so named because they have been considered to produce adipocytes and fibroblasts, although they may have wider differentiation potential dependent on niche environment [97]. FAPs appear to have intricate reciprocal relationship with SCs. The absence of FAPs leads to impaired muscle regeneration, premature SC differentiation, depletion of SC pool and smaller regenerated fibres [98]. In contrast, $\mathrm{SC}$ ablation results in misregulation of fibroblasts and accumulation of fibrosis [98]. Furthermore, FAPs appear to promote SC myogenesis by release of pro-myogenic cytokines [99]. Strikingly, FAPs in young $m d x$ mice have now been shown to become permissive to myogenesis, which has been revealed by treatment with 
epigenetic modifying histone deacetylase (HDAC) inhibitors [100] [97]. These studies highlight the complexity in regenerating muscles of diverse cell cross talk and the environmental influence on the reprogramming of cells.

\subsection{Pluripotent Stem Cells (ES/iPS cells)}

A relatively new strategy that holds great potential for future therapeutic application is the use of skeletal myogenic progenitors derived from pluripotent embryonic stem (ES) or induced pluripotent stem (iPS) cells. Because pluripotent stem cells can be maintained indefinitely in the undifferentiated state in the presence of specific culture conditions while retaining the ability to differentiate into multiple lineages in vitro, these cells represent an attractive option to generate large numbers of specific cell populations for regenerative medicine without the hurdles associated with the expansion of adult tissue-specific stem cells (see Fig.2). Although initial studies focused on the generation of skeletal muscle cells utilizing ES cells, most emphasis is now given to reprogrammed iPS cells since these bypass the ethical issues associated with ES cells as well as the potential problems associated with immunological mismatch. The reprogramming of somatic cells (skin fibroblasts, blood cells, among others) into iPS cells typically involves the introduction of the reprogramming factors Oct4, Klf4, Sox2, and c-Myc [91,101-103]. Because this technology enables the generation of patient-specific iPS cells that could be used for autologous transplantation (Fig. 2), there has been intense research aiming to replace original retroviral vectors [91] with non-integrating methods to deliver reprogramming factors and to enhance efficiency of reprograming, as reviewed [104]. Nevertheless there are many safety issues with iPS cells that will need extensive exploration before a clinical trial takes place.

\section{3..1. Myogenesis from ES/iPS cells and the effect of Pax3/Pax7 induction-}

Obviously, a critical requirement to move this strategy forward is the development of iPSderived tissue-specific stem cells with proven in vivo therapeutic potential. Differently from other lineages, like blood [105] [106] and cardiac muscle [107], skeletal myogenesis is extremely inefficient during in vitro differentiation of pluripotent stem cells. It has been hypothesized that this is due to the lack of inductive signals necessary for proper patterning of paraxial mesoderm and subsequent activation of the myogenic program since key embryonic structures (i.e. somite, neural tube, notochord) are not well recapitulated in this in vitro system [108]. This hurdle has been overcome by activating the myogenic program through transient induction of the myogenic master regulators, Pax 3 or Pax7, during early mesoderm development (see Fig. 1). This approach allows for the in vitro generation of large quantities of early embryonic skeletal myogenic progenitors from mouse and human pluripotent stem cells [108] [109] [110]. Studies involving the transplantation of these cells into several models of muscular dystrophy have demonstrated myofibre and SC engraftment that is accompanied by improvement in muscle force generation [108,111] [109,110] [112]. In the case of human iPS derived skeletal muscle progenitors, long-lasting engraftment has been reported in a cohort of mice at 46 weeks post- transplantation, without teratoma or abnormal cell growth [110].

3..2. Muscle differentiation without genetic manipulation-Following these encouraging results, several reports have documented strategies to generate skeletal muscle 
progenitors without genetic modification using mouse [113,114] or human [115] [116,117] pluripotent stem cells, and these vary dramatically in efficiency as well as length of in vitro differentiation protocol. Some of these studies have not reported in vivo regenerative potential of generated myogenic cells [115,117] or used a mouse disease model [106]. Nevertheless, these strategies show that it is possible to induce the myogenic program in differentiating pluripotent stem cells without genetic modification, and thus, further in vivo studies will be instrumental to assess the regenerative potential of generated myogenic cells.

3..3. MyoD overexpression-MyoD, known as the muscle determination factor, has also been used to generate engraftable muscle cells from human iPS cells as shown following their transplantation into mouse models of muscular dystrophy [118] [119]. Because MyoD is downstream of Pax3/Pax7 in the myogenic hierarchy (Fig.1), the ability of in vitro generated cells to seed the SC compartment and thus confer long-term engraftment is debatable. Nevertheless, one of these studies documented functional amelioration of the dystrophic phenotype [119].

\section{3..4. Genetic correction of iPS cells and potential for autologous}

transplantation-As discussed above, iPS cells are particularly attractive for regenerative purposes due to the possibility of generating patient-specific iPS cells that could be used for autologous transplantation. In the case of MDs, this would require proper genetic correction. Proof-of-concept studies have been reported using mouse [120] and human [119] dystrophic iPS cells. In the former, transplantation of micro-utrophin-corrected iPS-derived skeletal myogenic progenitors, generated using Pax3 induction [108], resulted in the presence of donor-derived utrophin ${ }^{+}$myofibers and SCs, and enhanced muscle strength in engrafted muscles of dystrophin/utrophin double knockout (dKO) mice, a severe model for DMD [120]. The second study reports the genetic correction of patients affected by limb-girdle $2 \mathrm{~d}$ type MD [119], in which iPS-derived mesoangioblast/mesenchymal-like cells were modified with a lentiviral vector encoding the human a-sarcoglycan gene ( $S G C A)$. Transplantation of genetically corrected cells, following their myogenic differentiation using the MyoD method, led to beneficial results in a-sarcoglycan-null immunodeficient mice [119]

Taking into consideration that dystrophin is a very large gene, efforts to correct DMD iPS cells may be challenging. Nevertheless, complete genetic correction of DMD iPS cells has been reported using human artificial chromosome technology [13], although their myogenic differentiation ad in vivo potential has yet to be documented. More recently another group of investigators have applied targeted genome editing to correct the reading frame of DMD mutant fibroblasts [121], which theoretically could be used to generate corrected iPS cells.

Despite the fast pace and encouraging results so far, more extensive safety and efficacy studies are required to move this strategy to a clinical trial. It is reasonable to hypothesize that these cell preparations could also benefit from the use of scaffolds, although this has not been reported to date. 


\section{Conclusions}

In this review we have discussed the importance of skeletal muscle to normal physiology and its tremendous regenerative capacity. We emphasize the susceptibility of skeletal muscle to sarcopenia and diseases, in particular the most debilitating muscle disease, muscular dystrophy. Satellite cells, the stem cells within the skeletal muscle, have a niche microenvironment that has a strong influence on regulating their function. Strategies for intervention, which may ameliorate the regenerative capacity of satellite cells, can hugely benefit from understanding the critical role of the niche. Biophysical and biochemical cues are identified as potent regulators of SC function, whose alteration takes place with disease and aging. The in vitro expansion of SC numbers for therapeutic use is limiting, but the engineering of biomaterial-based platforms that mimic the SC niche are making great progress in overcoming this hurdle. Based on the caveat of the low frequency of SCs, and the required expansion to obtain enough cell numbers, as well as to enable genetic modification, other stem cell populations have been investigated including stromal cells, and induced pluripotent stem cells. The continued intense research into SC function and iPS technology is truly mapping out a realistic therapeutic approach to much needed muscle degenerative disorders. The implementation of biomaterials and tissue engineering has helped overcome technical challenges towards this goal.

\section{Acknowledgements}

This work was supported by the Health Research Board Ireland Grant HRA/2009/79 (K.J.A.M) and by NIH grants R01 AR055299 and RC1AR058118 as well as MDA funding \# 238127 (R.C.R.P). We thank Cynthia DeKay (LHI/ UMN) for graphical design.

\section{References}

1. Yin H, Price F, Rudnicki MA. Satellite Cells and the Muscle Stem Cell Niche. Physiological Reviews. 2013; 93:23-67. [PubMed: 23303905]

2. MAURO A. Satellite cell of skeletal muscle fibers. J Biophys Biochem Cytol. 1961; 9:493-495. [PubMed: 13768451]

3. Petersen KF, Shulman GI. Pathogenesis of skeletal muscle insulin resistance in type 2 diabetes mellitus. The American Journal of Cardiology. 2002; 90:11-18.

4. Wang D, Zhong L, Nahid MA, Gao G. The potential of adeno-associated viral vectors for gene delivery to muscle tissue. Expert Opin. Drug Deliv. 2014:1-20.

5. DeFronzo RA, Tripathy D. Skeletal muscle insulin resistance is the primary defect in type 2 diabetes. Diabetes Care. 2009; 32(Suppl 2):S157-S163. [PubMed: 19875544]

6. Söderpalm A-C, Magnusson P, Ahlander A-C, Karlsson J, Kroksmark A-K, Tulinius M, et al. Low bone mineral density and decreased bone turnover in Duchenne muscular dystrophy. Neuromuscul. Disord. 2007; 17:919-928. [PubMed: 17627820]

7. Verma S, Anziska Y, Cracco J. Review of Duchenne muscular dystrophy (DMD) for the pediatricians in the community. Clin Pediatr (Phila). 2010; 49:1011-1017. [PubMed: 20724320]

8. Collins CA, Olsen I, Zammit PS, Heslop L, Petrie A, Partridge TA, et al. Stem cell function, selfrenewal, and behavioral heterogeneity of cells from the adult muscle satellite cell niche. Cell. 2005; 122:289-301. [PubMed: 16051152]

9. Mendell JR, Campbell K, Rodino-Klapac L, Sahenk Z, Shilling C, Lewis S, et al. Dystrophin immunity in Duchenne's muscular dystrophy. N. Engl. J. Med. 2010; 363:1429-1437. [PubMed: 20925545] 
10. Sampaolesi M, Blot S, D’Antona G, Granger N, Tonlorenzi R, Innocenzi A, et al. Mesoangioblast stem cells ameliorate muscle function in dystrophic dogs. Nature. 2006; 444:574-579. [PubMed: 17108972]

11. Muir LA, Chamberlain JS. Emerging strategies for cell and gene therapy of the muscular dystrophies. Expert Rev Mol Med. 2009; 11:e18. [PubMed: 19555515]

12. Vorgerd M. Therapeutic options in other metabolic myopathies. Neurotherapeutics. 2008; 5:579582. [PubMed: 19019309]

13. Kazuki Y, Hiratsuka M, Takiguchi M, Osaki M, Kajitani N, Hoshiya H, et al. Complete genetic correction of ips cells from Duchenne muscular dystrophy. Mol Ther. 2010; 18:386-393. [PubMed: 19997091]

14. Kobayashi YM, Rader EP, Crawford RW, Iyengar NK, Thedens DR, Faulkner JA, et al. Sarcolemma-localized nNOS is required to maintain activity after mild exercise. Nature. 2008; 456:511-515. [PubMed: 18953332]

15. Rahimov F, Kunkel LM. The cell biology of disease: Cellular and molecular mechanisms underlying muscular dystrophy. J. Cell Biol. 2013; 201:499-510. [PubMed: 23671309]

16. Tedesco FS, Hoshiya H, D'Antona G, Gerli MFM, Messina G, Antonini S, et al. Stem cellmediated transfer of a human artificial chromosome ameliorates muscular dystrophy. Science Translational Medicine. 2011; 3 96ra78.

17. Rovere-Querini P, Clementi E, Brunelli S. Nitric oxide and muscle repair: Multiple actions converging on therapeutic efficacy. Eur. J. Pharmacol. 2014; 730:181-185. [PubMed: 24269596]

18. Slack, J. Stem Cells: A Very Short Introduction. Oxford University Press; 2012.

19. Le Grand F, Jones AE, Seale V, Scimè A, Rudnicki MA. Wnt7a Activates the Planar Cell Polarity Pathway to Drive the Symmetric Expansion of Satellite Stem Cells. Cell Stem Cell. 2009; 4:535547. [PubMed: 19497282]

20. Emery AE. Population frequencies of inherited neuromuscular diseases--a world survey. Neuromuscul. Disord. 1991; 1:19-29. [PubMed: 1822774]

21. Mendell JR, Kissel JT, Amato AA, King W, Signore L, Prior TW, et al. Myoblast transfer in the treatment of Duchenne's muscular dystrophy. N. Engl. J. Med. 1995; 333:832-838. [PubMed: 7651473]

22. Sinha M, Jang YC, Oh J, Khong D, Wu EY, Manohar R, et al. Restoring systemic GDF11 levels reverses age-related dysfunction in mouse skeletal muscle. Science. 2014; 344:649-652. [PubMed: 24797481]

23. Tennyson CN, Klamut HJ, Worton RG. The human dystrophin gene requires 16 hours to be transcribed and is cotranscriptionally spliced. Nat. Genet. 1995; 9:184-190. [PubMed: 7719347]

24. Tinsley JM, Fairclough RJ, Storer R, Wilkes FJ, Potter AC, Squire SE, et al. Daily treatment with SMTC1100, a novel small molecule utrophin upregulator, dramatically reduces the dystrophic symptoms in the mdx mouse. PLoS ONE. 2011; 6:e19189. [PubMed: 21573153]

25. Koo T, Popplewell L, Athanasopoulos T, Dickson G. Triple trans-splicing adeno-associated virus vectors capable of transferring the coding sequence for full-length dystrophin protein into dystrophic mice. Hum. Gene Ther. 2014; 25:98-108. [PubMed: 24191945]

26. Lostal W, Kodippili K, Yue Y, Duan D. Full-Length Dystrophin Reconstitution with AdenoAssociated Viral Vectors. Hum. Gene Ther. 2014

27. Genetics JS. Chamberlain. A genetic intervention stands a skip away from clinical tests. Science. 2012; 338:1431-1432. [PubMed: 23239725]

28. Sacco A, Doyonnas R, Kraft P, Vitorovic S, Blau HM. Self-renewal and expansion of single transplanted muscle stem cells. Nature. 2008; 456:502-506. [PubMed: 18806774]

29. Fukada S-I, Ma Y, Ohtani T, Watanabe Y, Murakami S, Yamaguchi M. Isolation, characterization, and molecular regulation of muscle stem cells. Front. Physiol. 2013; 4:317. [PubMed: 24273513]

30. Rinaldi F, Perlingeiro RCR. Stem cells for skeletal muscle regeneration: therapeutic potential and roadblocks. Transl Res. 2014; 163:409-417. [PubMed: 24299739]

31. Bosnakovski D, Xu Z, Li W, Thet S, Cleaver O, Perlingeiro RCR, et al. Prospective Isolation of Skeletal Muscle Stem Cells with a Pax7 Reporter. Stem Cells. 2008; 26:3194-3204. [PubMed: 18802040] 
32. Arpke RW, Darabi R, Mader TL, Zhang Y, Toyama A, Lonetree C-L, et al. A new immuno-, dystrophin-deficient model, the NSG-mdx $(4 \mathrm{Cv})$ mouse, provides evidence for functional improvement following allogeneic satellite cell transplantation. Stem Cells. 2013; 31:1611-1620. [PubMed: 23606600]

33. Montarras D, Morgan J, Collins C, Relaix F, Zaffran S, Cumano A, et al. Direct isolation of satellite cells for skeletal muscle regeneration. Science. 2005; 309:2064-2067. [PubMed: 16141372]

34. Engler AJ, Sen S, Sweeney HL, Discher DE. Matrix Elasticity Directs Stem Cell Lineage Specification. Cell. 2006; 126:677-689. [PubMed: 16923388]

35. Gilbert PM, Havenstrite KL, Magnusson KEG, Sacco A, Leonardi NA, Kraft P, et al. Substrate Elasticity Regulates Skeletal Muscle Stem Cell Self-Renewal in Culture. Science. 2010; 329:1078-1081. [PubMed: 20647425]

36. Urciuolo A, Quarta M, Morbidoni V, Gattazzo F, Molon S, Grumati P, et al. Collagen VI regulates satellite cell self-renewal and muscle regeneration. Nature Communications. 2013; 4:1964.

37. Gillies AR, Lieber RL. Structure and function of the skeletal muscle extracellular matrix. Muscle Nerve. 2011; 44:318-331. [PubMed: 21949456]

38. Mann CJ, Perdiguero E, Kharraz Y, Aguilar S, Pessina P, Serrano AL, et al. Aberrant repair and fibrosis development in skeletal muscle. Skeletal Muscle. 2011; 1:21. [PubMed: 21798099]

39. Pelham RJ, Wang YL. Cell locomotion and focal adhesions are regulated by substrate flexibility. Proc. Natl. Acad. Sci. U.S.a. 1997; 94:13661-13665. [PubMed: 9391082]

40. Engler AJ, Griffin MA, Sen S, Bönnemann CG, Sweeney HL, Discher DE. Myotubes differentiate optimally on substrates with tissue-like stiffness: pathological implications for soft or stiff microenvironments. 2004; 166:877-887. [PubMed: 15364962]

41. Rosant C, Nagel M-D, Pérot C. Aging affects passive stiffness and spindle function of the rat soleus muscle. Exp. Gerontol. 2007; 42:301-308. [PubMed: 17118602]

42. Cosgrove BD, Sacco A, Gilbert PM, Blau HM. ARTICLE IN PRESS. Differentiation. 2009; 78:185-194. [PubMed: 19751902]

43. Raab M, Shin J-W, Discher DE. Matrix elasticity in vitro controls muscle stem cell fate in vivo. Stem Cell Res Ther. 2010; 1:38. [PubMed: 21144011]

44. Yang HS, Ieronimakis N, Tsui JH, Kim HN, Suh K-Y, Reyes M, et al. Nanopatterned muscle cell patches for enhanced myogenesis and dystrophin expression in a mouse model of muscular dystrophy. Biomaterials. 2014; 35:1478-1486. [PubMed: 24290810]

45. Bönnemann CG. The collagen VI-related myopathies: muscle meets its matrix. Nat Rev Neurol. 2011; 7:379-390. [PubMed: 21691338]

46. Serrano AL, Mann CJ, Vidal B, Ardite E. Myogenesis - Google Books, Current Topics in .... 2011

47. Conboy IM, Conboy MJ, Wagers AJ, Girma ER, Weissman IL, Rando TA. Rejuvenation of aged progenitor cells by exposure to a young systemic environment. Nature. 2005; 433:760-764. [PubMed: 15716955]

48. Carlson BM, Faulkner JA. Muscle transplantation between young and old rats: age of host determines recovery. Am. J. Physiol. 1989; 256:C1262-C1266. [PubMed: 2735398]

49. Cosgrove BD, Gilbert PM, Porpiglia E, Mourkioti F, Lee SP, Corbel SY, et al. Rejuvenation of the muscle stem cell population restores strength to injured aged muscles. Nat. Med. 2014:1-14. [PubMed: 24398945]

50. Bernet JD, Doles JD, Hall JK, Tanaka KK, Carter TA, Olwin BB. p38 MAPK signaling underlies a cell-autonomous loss of stem cell self-renewal in skeletal muscle of aged mice. Nat. Med. 2014:19. [PubMed: 24398945]

51. Sousa-Victor P, Gutarra S, García-Prat L, Rodriguez-Ubreva J, Ortet L, Ruiz-Bonilla V, et al. Geriatric muscle stem cells switch reversible quiescence into senescence. Nature. 2014; 506:316321. [PubMed: 24522534]

52. Mourikis P, Tajbakhsh S. Distinct contextual roles for Notch signalling in skeletal muscle stem cells. BMC Dev. Biol. 2014; 14:2. [PubMed: 24472470]

53. Gopinath SD, Webb AE, Brunet A, Rando TA. FOXO3 Promotes Quiescence in Adult Muscle Stem Cells during the Process of Self-Renewal. Stem Cell Reports. 2014; 2:414-426. [PubMed: 24749067] 
54. Bjornson CRR, Cheung TH, Liu L, Tripathi PV, Steeper KM, Rando TA. Notch signaling is necessary to maintain quiescence in adult muscle stem cells. Stem Cells. 2012; 30:232-242. [PubMed: 22045613]

55. Conboy IM, Conboy MJ, Smythe GM, Rando TA. Notch-mediated restoration of regenerative potential to aged muscle. Science. 2003; 302:1575-1577. [PubMed: 14645852]

56. Chakkalakal J, Brack A. Extrinsic Regulation of Satellite Cell Function and Muscle Regeneration Capacity during Aging. J Stem Cell Res Ther. 2012; (Suppl 11):001. [PubMed: 24678443]

57. Brack AS, Conboy MJ, Roy S, Lee M, Kuo CJ, Keller C, et al. Increased Wnt signaling during aging alters muscle stem cell fate and increases fibrosis. Science. 2007; 317:807-810. [PubMed: 17690295]

58. Brack AS, Conboy IM, Conboy MJ, Shen J, Rando TA. A temporal switch from notch to Wnt signaling in muscle stem cells is necessary for normal adult myogenesis. Cell Stem Cell. 2008; 2:50-59. [PubMed: 18371421]

59. von Maltzahn J, Renaud J-M, Parise G, Rudnicki MA. Wnt7a treatment ameliorates muscular dystrophy. Proc. Natl. Acad. Sci. U.S.a. 2012; 109:20614-20619. [PubMed: 23185011]

60. Juhas M, Bursac N. Engineering skeletal muscle repair. 2013; 24:880-886.

61. Kuraitis D, Berardinelli MG, Suuronen EJ, Musaro A. A necrotic stimulus is required to maximize matrix-mediated myogenesis in mice. Disease Models \& Mechanisms. 2013; 6:793-801.

[PubMed: 23471914]

62. Rossi CA, Flaibani M, Blaauw B, Pozzobon M, Figallo E, Reggiani C, et al. In vivo tissue engineering of functional skeletal muscle by freshly isolated satellite cells embedded in a photopolymerizable hydrogel. Faseb J. 2011; 25:2296-2304. [PubMed: 21450908]

63. Fuoco C, Salvatori ML, Biondo A, Shapira-Schweitzer K, Santoleri S, Antonini S, et al. Skeletal Muscle. Skeletal Muscle. 2012; 2:1-1. [PubMed: 22221535]

64. Seliktar D. Designing cell-compatible hydrogels for biomedical applications. Science. 2012; 336:1124-1128. [PubMed: 22654050]

65. Lutolf MP, Blau HM. Artificial stem cell niches. Adv. Mater. Weinheim. 2009; 21:3255-3268. [PubMed: 20882496]

66. Juhas M, Engelmayr GC, Fontanella AN, Palmer GM, Bursac N. Biomimetic engineered muscle with capacity for vascular integration and functional maturation in vivo. Proc. Natl. Acad. Sci. U.S.a. 2014

67. Dennis RG, Kosnik PE. Excitability and isometric contractile properties of mammalian skeletal muscle constructs engineered in vitro. In Vitro Cell. Dev. Biol. Anim. 2000; 36:327-335. [PubMed: 10937836]

68. Yan W, George S, Fotadar U, Tyhovych N, Kamer A, Yost MJ, et al. Tissue engineering of skeletal muscle. Tissue Eng. 2007; 13:2781-2790. [PubMed: 17880268]

69. Koffler J, Kaufman-Francis K, Shandalov Y, Yulia S, Egozi D, Dana E, et al. Improved vascular organization enhances functional integration of engineered skeletal muscle grafts. Proc. Natl. Acad. Sci. U.S.a. 2011; 108:14789-14794. [PubMed: 21878567]

70. Hinds S, Bian W, Dennis RG, Bursac N. The role of extracellular matrix composition in structure and function of bioengineered skeletal muscle. Biomaterials. 2011; 32:3575-3583. [PubMed: 21324402]

71. Carosio S, Barberi L, Rizzuto E, Nicoletti C, Del Prete Z, Musarò A. Generation of eX vivovascularized Muscle Engineered Tissue (X-MET). Sci Rep. 2013; 3:1420. [PubMed: 23478253]

72. Péault B, Rudnicki M, Torrente Y, Cossu G, Tremblay JP, Partridge T, et al. Stem and progenitor cells in skeletal muscle development, maintenance, and therapy. Mol Ther. 2007; 15:867-877. [PubMed: 17387336]

73. Meregalli M, Farini A, Sitzia C, Torrente Y. Advancements in stem cells treatment of skeletal muscle wasting. Front. Physiol. 2014; 5:48. [PubMed: 24575052]

74. Sarig R, Baruchi Z, Fuchs O, Nudel U, Yaffe D. Regeneration and transdifferentiation potential of muscle-derived stem cells propagated as myospheres. Stem Cells. 2006; 24:1769-1778. [PubMed: 16574751] 
75. Rouger K, Larcher T, Dubreil L, Deschamps J-Y, Le Guiner C, Jouvion G, et al. Systemic delivery of allogenic muscle stem cells induces long-term muscle repair and clinical efficacy in duchenne muscular dystrophy dogs. Am. J. Pathol. 2011; 179:2501-2518. [PubMed: 21924229]

76. Lavasani M, Robinson AR, Lu A, Song M, Feduska JM, Ahani B, et al. Muscle-derived stem/ progenitor cell dysfunction limits healthspan and lifespan in a murine progeria model. Nature Communications. 2012; 3:608.

77. McCullagh KJA. Can a young muscle's stem cell secretome prolong our lives? Stem Cell Res Ther. 2012; 3:19. [PubMed: 22643017]

78. Torrente Y, Belicchi M, Marchesi C, D’Antona G, Cogiamanian F, Pisati F, et al. Autologous transplantation of muscle-derived CD133+ stem cells in Duchenne muscle patients. Cell Transplant. 2007; 16:563-577. [PubMed: 17912948]

79. Benchaouir R, Meregalli M, Farini A, D’Antona G, Belicchi M, Goyenvalle A, et al. Restoration of human dystrophin following transplantation of exon-skipping-engineered DMD patient stem cells into dystrophic mice. Cell Stem Cell. 2007; 1:646-657. [PubMed: 18371406]

80. Meng J, Chun S, Asfahani R, Lochmüller H, Muntoni F, Morgan J. Human Skeletal Musclederived CD133(+) Cells Form Functional Satellite Cells After Intramuscular Transplantation in Immunodeficient Host Mice. Mol Ther. 2014; 22:1008-1017. [PubMed: 24569833]

81. Sampaolesi M, Torrente Y, Innocenzi A, Tonlorenzi R, D’Antona G, Pellegrino MA, et al. Cell therapy of alpha-sarcoglycan null dystrophic mice through intra-arterial delivery of mesoangioblasts. Science. 2003; 301:487-492. [PubMed: 12855815]

82. Dellavalle A, Sampaolesi M, Tonlorenzi R, Tagliafico E, Sacchetti B, Perani L, et al. Pericytes of human skeletal muscle are myogenic precursors distinct from satellite cells. Nat. Cell Biol. 2007; 9:255-267. [PubMed: 17293855]

83. Sampaolesi M. Molecular and cell-based therapies for muscle degenerations: a road under construction. 2014:1-13.

84. Ankrum JA, Ong JF, Karp JM. Mesenchymal stem cells: immune evasive, not immune privileged. Nature Biotechnology. 2014; 32:252-260.

85. Ichim TE, Alexandrescu DT, Solano F, Lara F, Campion RDN, Paris E, et al. Mesenchymal stem cells as anti-inflammatories: Implications for treatment of Duchenne muscular dystrophy. Cell. Immunol. 2010; 260:75-82. [PubMed: 19917503]

86. Griffin MD, Elliman SJ, Cahill E, English K, Ceredig R, Ritter T. Concise review: adult mesenchymal stromal cell therapy for inflammatory diseases: how well are we joining the dots? Stem Cells. 2013; 31:2033-2041. [PubMed: 23766124]

87. Markert CD, Atala A, Cann JK, Christ G, Furth M, Ambrosio F, et al. Mesenchymal stem cells: emerging therapy for Duchenne muscular dystrophy. Pm R. 2009; 1:547-559. [PubMed: 19627945]

88. Mizuno H. The potential for treatment of skeletal muscle disorders with adipose-derived stem cells. Current Stem Cell Research \& Therapy. 2010

89. Choi YS, Vincent LG, Lee AR, Dobke MK, Engler AJ. Mechanical derivation of functional myotubes from adipose-derived stem cells. Biomaterials. 2012; 33:2482-2491. [PubMed: 22197570]

90. Gang EJ, Darabi R, Bosnakovski D, Xu Z, Kamm KE, Kyba M, et al. Engraftment of mesenchymal stem cells into dystrophin-deficient mice is not accompanied by functional recovery. Experimental Cell Research. 2009; 315:2624-2636. [PubMed: 19460366]

91. Takahashi K, Yamanaka S. Induction of pluripotent stem cells from mouse embryonic and adult fibroblast cultures by defined factors. Cell. 2006; 126:663-676. [PubMed: 16904174]

92. Vedantham V, Hayashi Y, Bruneau BG, Srivastava D. Direct reprogramming of fibroblasts into functional cardiomyocytes by defined factors. Cell. 2010

93. Gonçalves MA, Janssen JM, Nguyen QG, Athanasopoulos T, Hauschka SD, Dickson G, et al. Transcription Factor Rational Design Improves Directed Differentiation of Human Mesenchymal Stem Cells Into Skeletal Myocytes. Mol Ther. 2011; 19:1331-1341. [PubMed: 21266958]

94. Nitahara-Kasahara Y, Hayashita-Kinoh H, Ohshima-Hosoyama S, Okada H, Wada-Maeda M, Nakamura A, et al. Long-term engraftment of multipotent mesenchymal stromal cells that 
differentiate to form myogenic cells in dogs with Duchenne muscular dystrophy. Mol Ther. 2012; 20:168-177. [PubMed: 21934652]

95. Sassoli C, Pini A, Chellini F, Mazzanti B, Nistri S, Nosi D, et al. Bone marrow mesenchymal stromal cells stimulate skeletal myoblast proliferation through the paracrine release of VEGF. PLoS ONE. 2012; 7:e37512. [PubMed: 22815682]

96. Uezumi A. Roles of nonmyogenic mesenchymal progenitors in pathogenesis and regeneration of skeletal muscle. 2014:1-11.

97. Faralli H, Dilworth FJ. Dystrophic muscle environment induces changes in cell plasticity. Genes Dev. 2014; 28:809-811. [PubMed: 24736840]

98. Murphy MM, Lawson JA, Mathew SJ, Hutcheson DA, Kardon G. Satellite cells, connective tissue fibroblasts and their interactions are crucial for muscle regeneration. Development. 2011; 138:3625-3637. [PubMed: 21828091]

99. Joe AWB, Yi L, Natarajan A, Le Grand F, So L, Wang J, et al. Muscle injury activates resident fibro/adipogenic progenitors that facilitate myogenesis. Nat. Cell Biol. 2010; 12:153-163. [PubMed: 20081841]

100. Saccone V, Consalvi S, Giordani L, Mozzetta C, Barozzi I, Sandoná M, et al. HDAC-regulated myomiRs control BAF60 variant exchange and direct the functional phenotype of fibroadipogenic progenitors in dystrophic muscles. Genes Dev. 2014; 28:841-857. [PubMed: 24682306]

101. Takahashi K, Tanabe K, Ohnuki M, Narita M, Ichisaka T, Tomoda K, et al. Induction of pluripotent stem cells from adult human fibroblasts by defined factors. Cell. 2007; 131:861-872. [PubMed: 18035408]

102. Wernig M, Meissner A, Foreman R, Brambrink T, Ku M, Hochedlinger K, et al. In vitro reprogramming of fibroblasts into a pluripotent ES-cell-like state. Nature. 2007; 448:318-324. [PubMed: 17554336]

103. Yu J, Vodyanik MA, Smuga-Otto K, Antosiewicz-Bourget J, Frane JL, Tian S, et al. Induced pluripotent stem cell lines derived from human somatic cells. Science. 2007; 318:1917-1920. [PubMed: 18029452]

104. Okano H, Nakamura M, Yoshida K, Okada Y, Tsuji O, Nori S, et al. Steps toward safe cell therapy using induced pluripotent stem cells. Circ. Res. 2013; 112:523-533. [PubMed: 23371901]

105. Wiles MV, Keller G. Multiple hematopoietic lineages develop from embryonic stem (ES) cells in culture. Development. 1991; 111:259-267. [PubMed: 1893864]

106. Kaufman DS, Hanson ET, Lewis RL, Auerbach R, Thomson JA. Hematopoietic colony-forming cells derived from human embryonic stem cells. Proceedings of the .... 2001

107. Klug MG, Soonpaa MH, Koh GY, Field LJ. Genetically selected cardiomyocytes from differentiating embronic stem cells form stable intracardiac grafts. J. Clin. Invest. 1996; 98:216224. [PubMed: 8690796]

108. Darabi R, Gehlbach K, Bachoo RM, Kamath S, Osawa M, Kamm KE, et al. Functional skeletal muscle regeneration from differentiating embryonic stem cells. Nat. Med. 2008; 14:134-143. [PubMed: 18204461]

109. Darabi R, Santos FNC, Filareto A, Pan W, Koene R, Rudnicki MA, et al. Assessment of the myogenic stem cell compartment following transplantation of Pax3/Pax7-induced embryonic stem cell-derived progenitors. Stem Cells. 2011; 29:777-790. [PubMed: 21374762]

110. Darabi R, Arpke RW, Irion S, Dimos JT, Grskovic M, Kyba M, et al. Human ES- and iPS-derived myogenic progenitors restore DYSTROPHIN and improve contractility upon transplantation in dystrophic mice. Cell Stem Cell. 2012; 10:610-619. [PubMed: 22560081]

111. Darabi R, Baik J, Clee M, Kyba M, Tupler R, Perlingeiro RCR. Engraftment of embryonic stem cell-derived myogenic progenitors in a dominant model of muscular dystrophy. Exp. Neurol. 2009; 220:212-216. [PubMed: 19682990]

112. Filareto A, Darabi R, Perlingeiro RCR. Engraftment of ES-Derived Myogenic Progenitors in a Severe Mouse Model of Muscular Dystrophy. J Stem Cell Res Ther. 2012; 10 
113. Sakurai H, Okawa Y, Inami Y, Nishio N, Isobe K-I. Paraxial mesodermal progenitors derived from mouse embryonic stem cells contribute to muscle regeneration via differentiation into muscle satellite cells. Stem Cells. 2008; 26:1865-1873. [PubMed: 18450822]

114. Chang H, Yoshimoto M, Umeda K, Iwasa T, Mizuno Y, Fukada S-I, et al. Generation of transplantable, functional satellite-like cells from mouse embryonic stem cells. Faseb J. 2009; 23:1907-1919. [PubMed: 19168704]

115. Borchin B, Chen J, Barberi T. Derivation and FACS-Mediated Purification of PAX3+/PAX7+ Skeletal Muscle Precursors from Human Pluripotent Stem Cells. Stem Cell Reports. 2013; 1:620-631. [PubMed: 24371814]

116. Xu C, Tabebordbar M, Iovino S, Ciarlo C, Liu J, Castiglioni A, et al. A zebrafish embryo culture system defines factors that promote vertebrate myogenesis across species. Cell. 2013; 155:909_ 921. [PubMed: 24209627]

117. Hosoyama T, McGivern JV, Van Dyke JM, Ebert AD, Suzuki M. Derivation of Myogenic Progenitors Directly From Human Pluripotent Stem Cells Using a Sphere-Based Culture. Stem Cells Translational Medicine. 2014

118. Goudenege S, Lebel C, Huot NB, Dufour C, Fujii I, Gekas J, et al. Myoblasts Derived From Normal hESCs and Dystrophic hiPSCs Efficiently Fuse With Existing Muscle Fibers Following Transplantation. Mol Ther. 2012; 20:2153-2167. [PubMed: 22990676]

119. Tedesco FS, Gerli MFM, Perani L, Benedetti S, Ungaro F, Cassano M, et al. Transplantation of genetically corrected human iPSC-derived progenitors in mice with limb-girdle muscular dystrophy. Science Translational Medicine. 2012; 4 140ra89.

120. Filareto A, Parker S, Darabi R, Borges L, Iacovino M, Schaaf T, et al. An ex vivo gene therapy approach to treat muscular dystrophy using inducible pluripotent stem cells. Nature Communications. 2013; 4:1549.

121. Ousterout DG, Perez-Pinera P, Thakore PI, Kabadi AM, Brown MT, Qin X, et al. Reading frame correction by targeted genome editing restores dystrophin expression in cells from Duchenne muscular dystrophy patients. Mol Ther. 2013; 21:1718-1726. [PubMed: 23732986]

122. Troy A, Cadwallader AB, Fedorov Y, Tyner K, Tanaka KK, Olwin BB. Coordination of satellite cell activation and self-renewal by Par-complex-dependent asymmetric activation of $\mathrm{p} 38 \mathrm{a} / \mathrm{\beta}$ MAPK. Cell Stem Cell. 2012; 11:541-553. [PubMed: 23040480]

123. Sacco A, Mourkioti F, Tran R, Choi J, Llewellyn M, Kraft P, et al. Short telomeres and stem cell exhaustion model Duchenne muscular dystrophy in mdx/mTR mice. Cell. 2010; 143:1059-1071. [PubMed: 21145579]

124. Aguennouz M, Vita GL, Messina S, Cama A, Lanzano N, Ciranni A, et al. Telomere shortening is associated to TRF1 and PARP1 overexpression in Duchenne muscular dystrophy. Neurobiol Aging. 2011; 32:2190-2197. [PubMed: 20137830]

125. Carlson ME, Hsu M, Conboy IM. Imbalance between pSmad3 and Notch induces CDK inhibitors in old muscle stem cells. Nature. 2008; 454:528-532. [PubMed: 18552838]

126. Kitamoto T, Hanaoka K. Notch3 null mutation in mice causes muscle hyperplasia by repetitive muscle regeneration. Stem Cells. 2010; 28:2205-2216. [PubMed: 20960513]

127. Chakkalakal JV, Jones KM, Basson MA, Brack AS. The aged niche disrupts muscle stem cell quiescence. Nature. 2012; 490:355-360. [PubMed: 23023126]

128. Abou-Khalil R, Le Grand F, Pallafacchina G, Valable S, Authier F-J, Rudnicki MA, et al. Autocrine and paracrine angiopoietin 1/Tie-2 signaling promotes muscle satellite cell selfrenewal. Cell Stem Cell. 2009; 5:298-309. [PubMed: 19733541]

129. Liu W, Wen Y, Bi P, Lai X, Liu XS, Liu X, et al. Hypoxia promotes satellite cell self-renewal and enhances the efficiency of myoblast transplantation. Development. 2012; 139:2857-2865. [PubMed: 22764051] 


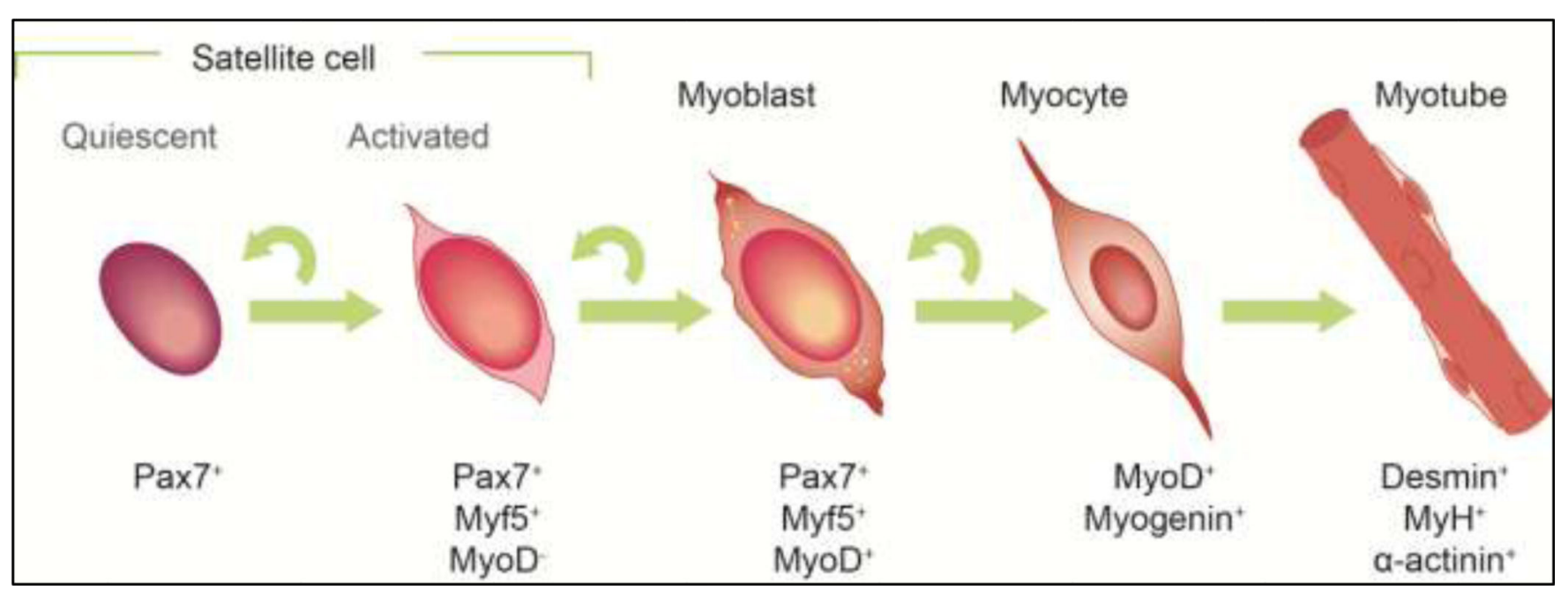

Fig. 1.

Differentiation progression during adult myogenesis: from satellite cells to differentiated myotubes. Upon muscle injury or with normal muscle turnover, satellite cells become activated from a quiescent state to an activated state. 


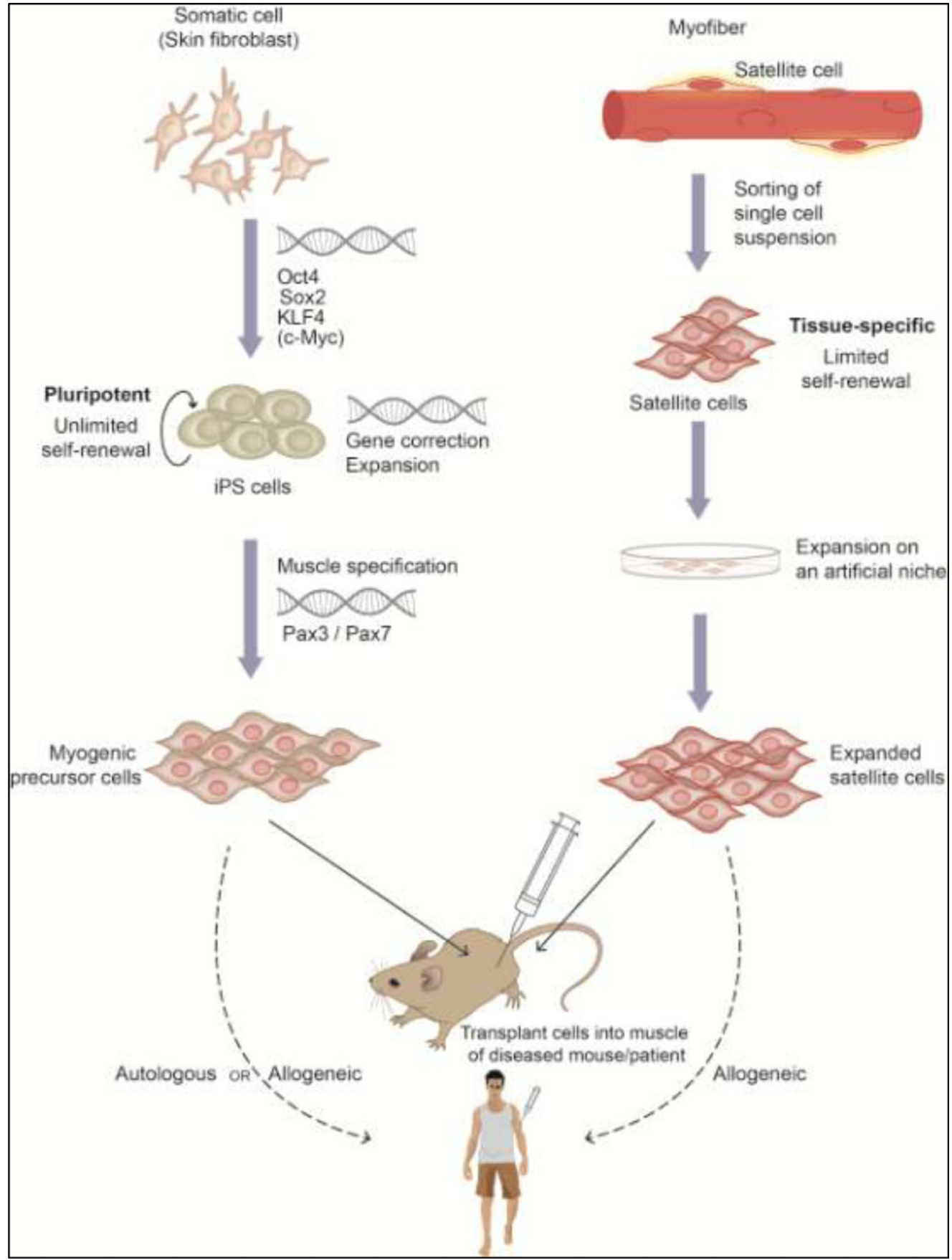

Fig. 2.

Outline of two potential strategies for skeletal muscle repair. The flow diagram shows on the left: reprogramming of somatic cells to derive iPS cells [91] and subsequent steps required to generate proliferating skeletal myogenic progenitors On the right, satellite cell isolation and subsequent in vitro expansion on artificial niches. Extensive pre-clinical studies in mouse models of muscular dystrophy are required before these cell preparations are tested in MD patients. 


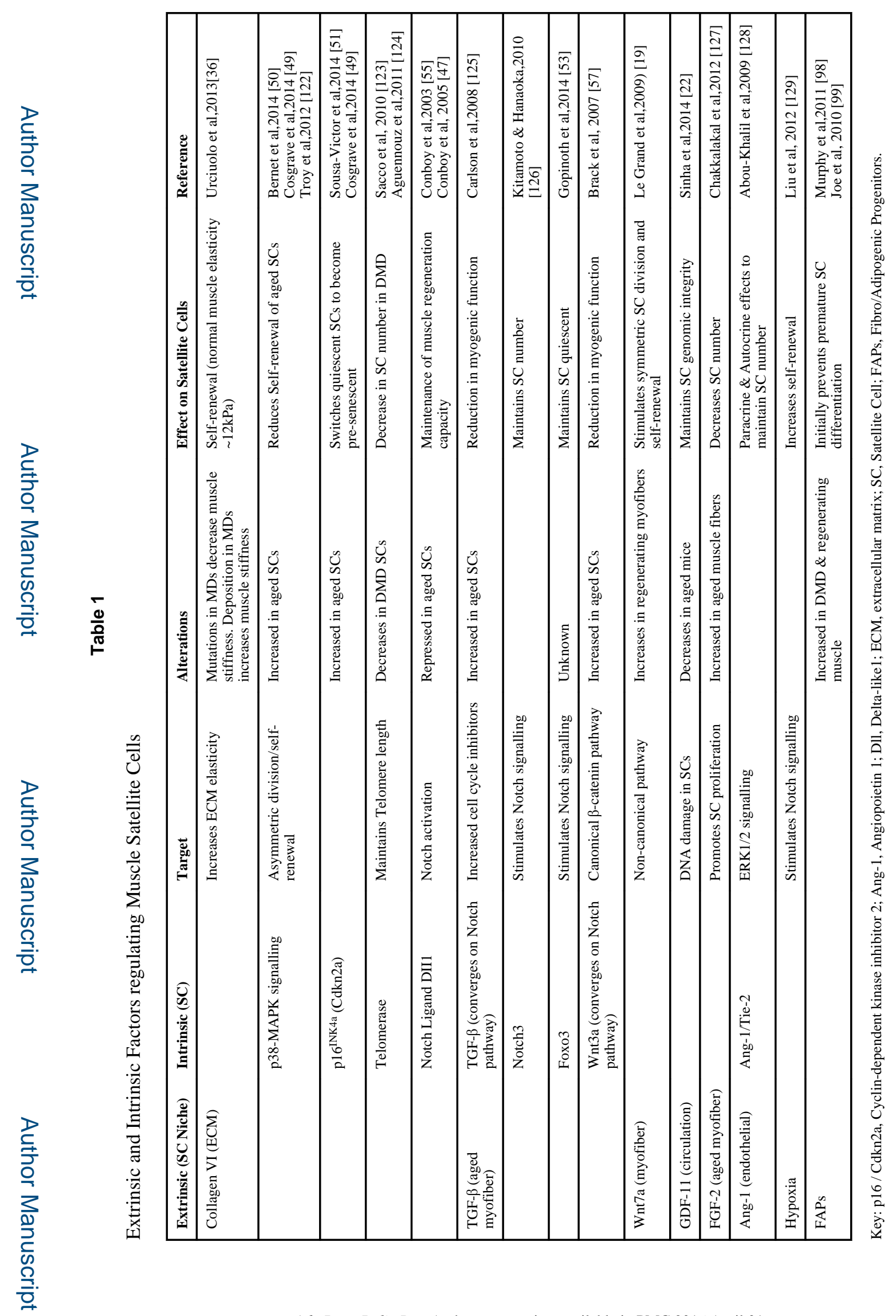

Adv Drug Deliv Rev. Author manuscript; available in PMC 2016 April 01. 